\title{
LRMSC Grade 3, Subcutaneous Tissue
}

National Cancer Institute

\section{Source}

National Cancer Institute. LRMSC Grade 3, Subcutaneous Tissue. NCI Thesaurus. Code C121178.

Severe induration and loss of subcutaneous tissue; field contracture $>10 \%$ linear measurement. 